\title{
Flavouring food: the contribution of chimpanzee behaviour to the understanding of Neanderthal calculus composition and plant use in Neanderthal diets
}

\author{
Sabrina Krief ${ }^{1,2}$, Camille Daujeard ${ }^{3}$, Marie-Hélène Moncel $^{3}$, \\ Noemie Lamon ${ }^{4,5} \&$ Vernon Reynolds ${ }^{5,6}$
}

\section{Introduction}

In a recent study, Hardy et al. (2012) examined ten samples of dental calculus from five Neanderthal individuals from El Sidrón in northern Spain (occupation dates between 47300 and $50600 \mathrm{BP}$ ). In calculus from a young adult, they discovered the presence of compounds (dihydroazulene, chamazulene and methylherniarin) that occur in yarrow (Achillea millefolium) and camomile (Matriarca chamomilla). In preference to other hypotheses, the authors proposed that these two plants were used for self-medication. In this paper, we do not reject the self-medication hypothesis, but our observations of wild chimpanzees in Uganda, at Sonso in the Budongo Forest Reserve and at Kanyawara and Sebitoli in Kibale National Park (separated by about $150 \mathrm{~km}$ ), as well as ethnological and palaeontological evidence, lead us to propose three other explanations for the presence of these compounds. In addition, data on Neanderthal behaviour suggest that their subsistence and technological strategies were complex.

\section{Hypotheses derived from wild chimpanzee behaviour}

Plants can be used to modify taste, i.e. to flavour or season food, or to reduce the risk of infection by parasites or bacteria present in the digestive tracts of prey. Hardy et al. (2013b) reject the possibility that these two plants (yarrow and camomile) were consumed for their flavour; this is based on the assumption that Neanderthals did not have complex tastes. However, wild chimpanzees frequently mix different foods. In Uganda wild chimpanzees

1 Eco-anthropologie et ethnobiologie, UMR 7206, Muséum national d'Histoire naturelle, 43 Rue Buffon, 75005 Paris, France

Sebitoli Chimpanzee Project, Sebitoli UWA Station, Fort Portal, Uganda

3 Préhistoire, Institut de Paléontologie Humaine, UMR 7194, Muséum national d'Histoire naturelle, 1 Rue René Panhard, 75013 Paris, France

Institut de Biologie, Université de Neuchâtel, Rue Emile-Argand 11, Neuchâtel 2000, Switzerland

Budongo Conservation Field Station, PO Box 362, Masindi, Uganda

School of Anthropology, Oxford University, 51-53 Banbury Road, Oxford, UK 
Table 1. Leaves chewed with red colobus prey hunted by chimpanzees in Kanyawara, Kibale National Park, Uganda.

\begin{tabular}{llll}
\hline Ingestion order & Leaf species chewed with meat & Part of prey & Chimpanzee consumer \\
\hline 1,8 & Diospyros abyssinica & abdominal muscles & KK (adult male) \\
2,7 & Chrysophyllum albidum & stomach and intestine & AJ (adult male) \\
& & LR (adult female) \\
3,4 & Uvariopsis congensis & carcass & LR (adult female) \\
5 & Teclea nobilis & carcass & KK (adult male) \\
6 & Antiaris toxicaria & carcass & OG (adult female) \\
$9,10,11$ & Bosqueia phoberos & carcass & OU (adult female) \\
& & & OG (juvenile male) \\
12 & Urera sp. & OT (juvenile female) \\
13 & Trema orientalis & abdominal organs & AJ (adult male) \\
\hline
\end{tabular}

have been observed chewing leaves with the meat of mammalian prey and with wasp combs. The addition of plants to food or water is therefore not a specifically human trait, and the process does not necessarily involve complex cognitive capacities.

The vegetation added to food or water in Kanyawara (Tables $1 \& 2$ ) is not part of the chimpanzees' normal diet. Chimpanzees prey on the colobus monkey, and they were observed chewing leaves while eating different parts of the colobus; among these were several plant species known for their biological properties. These included: Antiaris toxicaria (latex), which contains cardiotonic cardenolides - the plant is toxic and is used as dart poison by local people (Carter et al. 1997); Uvariopsis congensis, the leaves of which are rich in acetogenins such as annonacin and gigantotrecin, which have antiparasitic qualities; and Diospyros abyssinica leaves. Two molecules that we isolated from Diospyros abyssinica leaves (binaphthoquinones named diospyrin and isodiospyrin) inhibit the growth of tumour cells and kill parasites in culture (Krief et al. 2006) (Table 1). Eaten in large quantities, leaves containing bioactive compounds can be poisonous. Most of them have a strong, bitter taste, which reduces the likelihood of any creature ingesting a large quantity. Only a few leaves of each pharmacologically active species were eaten with animal material, preventing the poisoning that could result if a single species was eaten in a large quantity. For example, an adult female chimpanzee (LR) who hunted and consumed a red colobus monkey ate three different species of plant leaves with the monkey. Some species of plants are recorded as being used repeatedly either with meat or with wasp comb. Diospyros abyssinica was consumed on six different occasions by six different chimpanzees.

We find it unlikely that the leaves consumed with the prey were for self-medication to reduce a parasitic burden unrelated to the meat consumption. There are three reasons for this: the first is that all members of the party consuming the meat added leaves to it and it is unlikely that they were all suffering the same parasitic infection simultaneously and coincidentally with meat consumption, which is rare. The second is that these species of plants, which are abundant in their habitat, were not part of the chimpanzees' diet in the

(C) Antiquity Publications Ltd, 2015 
Table 2. Plant species used as sponges to drink water and chewed with wasp combs and colobus meat in Kanyawara (K) and Sebitoli (S), Kibale NP.

\begin{tabular}{|c|c|c|c|}
\hline \multirow[b]{2}{*}{$\begin{array}{l}\text { Plant species used } \\
\text { in association }\end{array}$} & \multicolumn{3}{|c|}{ Context, individual and date of use } \\
\hline & Drinking water & $\begin{array}{l}\text { Wasp comb } \\
\text { consumption }\end{array}$ & Colobus meat \\
\hline Ficus urceolaris & & KK (K: 2/09/07) & \\
\hline Ficus dawei & & & $\begin{array}{l}\text { MO (S:13/05/14) } \\
\text { LV (S:13/05/14) }\end{array}$ \\
\hline Ficus sur & & & KW (S : 8/05/14) \\
\hline \multirow{5}{*}{ Diospyros abyssinica } & & LR (K: 22/08/07) & KK (K: 5/10/08) \\
\hline & & AT (K: 6/08/07) & KE (S:13/05/14) \\
\hline & & PB (K: 30/07/07) & \\
\hline & & ST (K: 30/5/07) & \\
\hline & & AL (K: 18/07/07) & \\
\hline Acalypha ornata & $\mathrm{TJ}(28 / 12 / 07)$ stream & QT (K: 30/07/07) & \\
\hline Aframomum sp. & PB $(28 / 12 / 07)$ stream & ST (K: 30/5/07) & \\
\hline Bosqueia phoberos & LS $(20 / 12 / 07)$ tree hole & & $\begin{array}{l}\text { OU, OT, OG (K: } 21 / 03 / 07) \\
\text { OU, OG, OT (K: 5/10/08) }\end{array}$ \\
\hline Chaetacme aristata & & MS (K: 23/7/07) & \\
\hline Rothmania urcelliformis & & & OG (K: 21/03/07) \\
\hline Chrysophyllum albidum & & & AJ, LR (K: 5/10/08) \\
\hline Uvariopsis congensis & & & LR, KK (K: 5/10/08) \\
\hline Teclea nobilis & & & LR (K: 5/10/08) \\
\hline Trema orientalis & & & AJ (K: 5/10/08) \\
\hline Antiaris toxicaria & & & OG (K: 5/10/08) \\
\hline \multirow[t]{2}{*}{ Urera sp. } & & & QT (K: 5/10/08) \\
\hline & & & KE (S: $13 / 05 / 14)$ \\
\hline
\end{tabular}

previous or following days. Finally, in the Sebitoli community (neighbouring Kanyawara), chimpanzees used the same leaf species (D. abyssinica, Urera sp.) as in Kanyawara but also ate two ficus species (Ficus sur and Ficus dawei), which were not recorded being eaten in Kanyawara, where they are also present. This apparent preference seen in individuals and social groups of chimpanzees deserves more attention; preference for particular plant seasonings could be a strong indication that they are used for flavour, with individual preferences influenced by social traditions. In Sonso, out of four occasions when chimpanzees were observed eating wasp combs, they added leaves once (unidentified climber species). In Kanyawara and Sonso, leaves were also used to drink running water from streams or rivers (i.e. the leaves are used when unnecessary, as well as being a necessary tool to get water from a hole in a tree).

The strong, bitter taste of the leaves may modify the flavour of the viscera, muscles, organs or water. In a French cookbook, a recipe proposes cooking a blanquette of veal with camomile (Le Divellec \& Pécau 2000). The bitter taste of the cooked plant does not necessarily disappear completely; camomile, for example, remains bitter when infused.

Leaves can also be used to reduce the risk of infection by parasites or bacteria that may be present in the water and in the digestive tract of the prey (Krief et al. 2006). In Sonso, (C) Antiquity Publications Ltd, 2015 
observers also noted that chimpanzees ate more leaves when eating stomach and intestines in comparison to other parts of the anatomy of prey. The use of spices in human cooking may be explained in evolutionary terms because it decreases the risk of microbial infection and helps to digest food (Sherman \& Billing 1999). Yarrow and camomile flowers have moderate antimicrobial properties and weak antibacterial and antifungal properties (McKay \& Blumberg 2006; Bruneton 2009), we therefore cannot rule out the possibility that these herbs might have been used by humans or hominids in similar ways to those seen in chimpanzees, i.e. adding aromatic plants to modify taste, improve texture (Wobber et al. 2008; Wrangham 2009) or limit the risk of parasitic or bacterial contamination.

The mixing of several food items has also been reported in another, non-nutritional context: chimpanzees in Kanyawara often eat soil shortly before or after eating the leaves of Trichilia rubescens (Klein et al. 2008). These leaves contain anti-malarial compounds (Krief et al. 2004). While soil alone is not active against the malarial parasite Plasmodium falciparum, the soil and leaf combination has significantly higher anti-malarial properties than leaves alone. Mixing the leaves with clay may increase the available biologically active leaf compounds, possibly by adsorbing these otherwise inactive compounds and bonding them to soil particles, with the result that the soil-leaf mixture then boosts the pharmaceutical properties of the individual components.

The secondary metabolites in the calculus may come from indirect consumption of the digestive content of prey; chimpanzees preferentially consume the stomach and digestive tract of their prey. As in some human societies, in which raw stomach and intestines are highly prized, these organs were eaten first by chimpanzees in Sonso and Kanyawara. In response to Hardy et al. (2013b), it has recently been suggested that plant residues from the dental calculus of Neanderthals may have accumulated because they were eating the stomach content of herbivorous animals that they hunted (Buck \& Stringer 2014). These authors suggest that the ingestion of chyme may be of nutritional value because it increases the intake of plant material, notably in cold periods or at high altitude, situations when plant foods are rare. However, chimpanzee feeding behaviour shows that for our closest relatives, the reason for consuming stomach content first is not the low availability of carbohydrates due to plant scarcity, as plants form the main part of their diet. Stomach and intestines seem to be simply their favourite parts of the prey. This is consistent with ethnographic accounts that describe such organs as delicacies (Fediuk 2000; Speth 2010). Westernised Inuit explain that they crave this food because it has become rare in their modern diet compared with their traditional diet, and they compensate for the loss of intestines by eating industrial sour cheese (Binford 1978; Fediuk 2000; Gadsby \& Steele 2004; Speth 2010). Neanderthals might have appreciated this part of their prey's body and thus indirectly consumed its content, including yarrow and camomile.

Finally, in agreement with Hardy et al. (2013b), we cannot exclude the possibility that Neanderthals were able to medicate (chimpanzees observe conspecifics selecting and swallowing non-nutritional plants). Nevertheless, we do not understand why the authors propose self-medication rather than medication more generally. In their article, the authors note that Neanderthals had the genetic capability for language and engaged in conspecific care. There are several known Neanderthal individuals, wounded or edentulous, who were probably only able to survive because they received support from other group members 
(Gracia et al. 2009; Hublin 2009). The earliest edentulous Homo erectus at Dmanisi (Georgia), dated to $c$. 1.77 mya, and a Middle Pleistocene human with congenital cranial deformities must have received attention and assistance from others to survive with such disabilities (Lordkipanidze et al. 2005). For this reason, we consider that care and medicinal substances might have been provided to sick individuals by conspecifics. In chimpanzees, we usually assume they are self-medicating and not engaging in conspecific care because: 1) they are probably not able to diagnose pain and malaise when their conspecific is sick if he or she is not expressing and communicating clinical signs; and 2) chimpanzees probably have a lower level of empathy than that held by Neanderthals.

However, medication or self-medication as a therapeutic practice is supposed to be a rare and irregular behaviour: secondary compounds are usually toxic, a feature mentioned by Hardy et al. (2013b), so the ingested dose must be low. The fact that plants were integrated into the calculus sample suggests frequent ingestion to the extent that the compounds were deposited into the calculus. In that case, the compounds might have had a low level of pharmacological effect and should rather be considered as a complement to the diet instead of as drugs with highly active pharmacological properties. The herbs can be considered rather as aromatic plants with mild properties preventing minor disorders, used as calming infusions (camomile) or digestive infusions (yarrow), and not akin to therapeutic medicine. In order to explain the fact that insects use secondary compounds of plants, de Roode et al. (2013) reaffirmed that boundaries between nutrients, medicines and toxins are permeable and do not necessarily mean that self-medicating individuals are conscious of treating themselves. Such practices may be rather prophylactic and considered in the context of 'food as medicine and medicine as food', as proposed by Etkin and Ross (1982), assuming that the diet can contribute to health maintenance if low-content bioactive compounds are eaten regularly (prophylaxis).

\section{Complex cooking practices of Neanderthals}

The presence of cooked carbohydrates, esters, phenols, pyrene and florathene in calculus samples from El Sidrón supports the hypothesis that Neanderthals were cooking plant food and perhaps smoking food (Hardy et al. 2012), confirming that they were able to practice different food-processing techniques (Hardy et al. 2013a). It is suggested that, among other cooking methods, roasting, heating or even potentially boiling to make soup, stew or stock might have been used by Neanderthals (Henry et al. 2011; Zielinski 2013). Adding fat is particularly necessary in a meat-rich diet to compensate for the lack of carbohydrate and to increase the gluconeogenesis process (Stefansson 1944; Speth \& Spielmann 1983; Brink 1997; Speth 2010). The skeleton is a good source of fat in animals, particularly when they die from starvation in late winter and spring. Neanderthals exploited the fat marrow and the bone grease of their prey's carcasses thanks to various processing methods such as systematically breaking marrow bones or smashing and crushing cancellous bones. Despite few archaeological examples, the numerous small bone fragments recovered from Middle Palaeolithic settlements, and the various benefits known to be gained from boiling bones, allow us to consider the making of fat stocks as a likely cooking method among Neanderthals (Daujeard 2008). Boiling crushed bone is known to facilitate bone fat extraction and even

(C) Antiquity Publications Ltd, 2015 
to improve vitamin and mineral availability for the consumer (Binford 1978; Speth \& Spielmann 1983; Lupo \& Schmitt 1997; Outram 2001; Church \& Lyman 2003; Speth 2004). Such stocks were probably consumed during periods when prey, suffering from starvation, provided low-fat meat to hunters, but can also be related to cultural food processing. Such a variety of practices, combined with the fact that the samples from El Sidrón reveal the presence of smoke-related compounds, show that Neanderthals were using food processing at least as complex as flavouring food with plant material. These subsistence behaviours are observed at sites located both in northern and southern Europe, contemporaneously with occupation at El Sidrón (50-47 ka; Lalueza-Fox et al. 2011) and earlier. Technical strategies, land-use patterns, raw material and ochre procurement and use, and pyrotechnic ability all suggest a highly complex Neanderthal world, in which complex food-processing systems would not be surprising (Fernandes et al. 2008; Daujeard \& Moncel 2010; Hardy \& Moncel 2011; Roebroeks \& Villa 2011; Moncel et al. 2012; Roebroeks et al. 2012; Ecker et al. 2013; Hardy et al. 2013a).

In conclusion, if the presence of camomile and yarrow in calculus samples from Neanderthals can be explained as self-medication, we suggest that the data are not sufficient to exclude other deliberate food practices such as the consumption of the stomach contents of prey (thereby indirectly consuming plant material) or the addition of plants as aromatics or spices, deliberately mixing them with the prey to decrease the risk of infection.

\section{Acknowledgements}

We are grateful to the Uganda Wildlife Authority and the Uganda National Council for Science and Technology for authorisation to conduct research in Uganda, and to Ugandan field assistants for their help. Data from KNP have been collected in the context of a MoU between MNHN, UWA and Makerere University. S. Krief is grateful to the MNHN/ATM 16, ANR JC-JC SAFAPE, Projet pour la Conservation des Grands Singes for supporting and funding her research in KNP.

\section{References}

BINFORD, L.R. 1978. Nunamiut ethnoarchaeology. New York: Academic Press.

BRINK, J.W. 1997. Fat content in leg bones of Bison bison, and applications to archaeology. Journal of Archaeological Science 24: 259-74. http://dx.doi.org/10.1006/jasc.1996.0109

BuCK, L.T. \& C.B. STRINGER. 2014. Having the stomach for it: a contribution to Neanderthal diets? Quaternary Science Reviews 96: 161-67. http://dx.doi.org/10.1016/j.quascirev.2013.09.003

Bruneton, J. 2009. Pharmacognosie, phytochimie, plantes médicinales. Paris: Lavoisier.

Carter, C.A., E.A. Gray, T.L. SchneIder, C.M. LovetT JR, L. SCOTt, A.C. Messer \& D.P. RICHARDSON. 1997. Toxicarioside B and toxicarioside C. New cardenolides isolated from Antiaris toxicaria latex-derived dart poison. Tetrahedron 53: 16959-68. http://dx.doi.org/10.1016/S0040-4020(97)101740
CHURCH, R.R. \& R.L. LYMAN. 2003. Small fragments make small differences in efficiency when rendering grease from fractured artiodactyl bones by boiling. Journal of Archaeological Science 30: 1077-84. http://xdx.doi.org/10.1016/S0305-4403(03)00010-4

DAUJEARD, C. 2008. Exploitation du milieu animal par les Néanderthaliens dans le sud-est de la France (British Archaeological Reports international series 1867). Oxford: John \& Erica Hedges.

Daujeard, C. \& M.-H. MonCel. 2010. On Neanderthal subsistence strategies and land use: a regional focus on the Rhone Valley area in southeastern France. Journal of Anthropological Archaeology 29: 368-91.

http://dx.doi.org/10.1016/j.jaa.2010.05.002

Ecker, M., H. Bocherens, M-A. Julien, F. Rivals, J-P. Raynal \& M.-H. Moncel. 2013. Middle Pleistocene ecology and Neanderthal subsistence: insights from stable isotope analyses in Payre (Ardèche, southeastern France). Journal of Human Evolution 65: 363-73. http://dx.doi.org/10.1016/j.jhevol.2013.06.013

(C) Antiquity Publications Ltd, 2015 


\section{Flavouring food}

ETKIN, N.L. \& P.J. Ross. 1982. Food as medicine and medicine as food: an adaptive framework for the interpretation of plant utilization among the Hausa of northern Nigeria. Social Science \& Medicine 16: 1559-73. http://dx.doi.org/10.1016/0277-9536(82)90167-8

FEDIUK, K. 2000. Vitamin C in the Inuit diet: past and present. Unpublished PhD dissertation, McGill University.

Fernandes, P., J.-P. Raynal \& M.-H. Moncel. 2008. Middle Palaeolithic raw material gathering territories and Neandertal mobility in the southern Massif Central of France: first results from a petro-archaeological study on flint. Journal of Archaeological Science 35: 2357-70. http://dx.doi.org/10.1016/j.jas.2008.02.012

Gadsby, P. \& L. STeEle. 2004. The Inuit paradox. Discover, October 2004, pp. 12-14.

Gracia, A., J.L. Arsuaga, I. Martínez, C. Lorenzo, J.M. Carretero, J.M. Bermúdez de Castro \& E. Carbonell. 2009. Craniosynostosis in the Middle Pleistocene human cranium 14 from the Sima de los Huesos, Atapuerca, Spain. Proceedings of the National Academy of Sciences of the USA 106: 6573-78. http://dx.doi.org/10.1073/ pnas.0900965106

Hardy, B.L. \& M.-H. MonCEL. 2011. Neanderthal use of fish, mammals, birds, starchy plants and wood 125-250,000 year ago. PLoS ONE 6(8): e23768. http://dx.doi.org/10.1371/journal.pone.0023768

Hardy, B.L., M.-H. Moncel, C. Daujeard, P. Fernandes, P. Béarez, E. Desclaux, M.G. Chacon Navarro, S. Puaud \& R. GALLOTTI. 2013a. Impossible Neanderthals? Making string, throwing projectiles and catching small game during Marine Isotope Stage 4 (Abri du Maras, France). Quaternary Science Review 82: 23-40. http://dx.doi.org/10.1016/ j.quascirev.2013.09.028

Hardy, K., S. Buckley, M.J. Collins, A. Estalrrich, D. BROTHWELL, L. COPELAND,

A. García-Tabernero, S. Garcia-Vargas, M. DE la Rasilla, C. Lalueza-Fox, R. Huguet, M. Bastir, D. Santamaría, M. Madella, J. Wilson, A. Fernandez Cortés \& A. Rosas. 2012. Neanderthal medics? Evidence for food, cooking, and medicinal plants entrapped in dental calculus. Naturwissenschaften 99: 617-26. http://dx.doi.org/10.1007/s00114-012-0942-0

Hardy, K., S. Buckley \& M. HuffMAn. 2013b. Neanderthal self-medication in context. Antiquity 87: 873-78.
Henry, A.G., A.S. Brooks \& D.R. Piperno. 2011. Microfossils in calculus demonstrate consumption of plants and cooked foods in Neanderthal diets (Shanidar III, Iraq; Spy I and II, Belgium). Proceedings of the National Academy of Sciences of the USA 108: 486-91.

http://dx.doi.org/10.1073/pnas.1016868108

Hublin, J.-J. 2009. The prehistory of compassion.

Proceedings of the National Academy of Sciences of the USA 106: 6429-30.

http://dx.doi.org/10.1073/pnas.0902614106

KLeIN, N., F. FröHlich \& S. KRIEF. 2008. Geophagy: soil consumption enhances the bioactivities of plants eaten by chimpanzees. Naturwissenschaften 95: 325-31. http://dx.doi.org/10.1007/s00114-007-0333-0

Krief, S., M.T. Martin, P. Grellier, J. Kasenene \& T. SÉvENET. 2004. Novel antimalarial compounds isolated in a survey of self-medicative behavior of wild chimpanzees in Uganda. Antimicrobial Agents and Chemotherapy 48: 3196-99.

http://dx.doi.org/10.1128/AAC.48.8.3196-3199. 2004

Krief, S., R.W. Wrangham \& D. Lestel. 2006. Diversity of items of low nutritional value ingested by chimpanzees from Kanyawara, Kibale National Park, Uganda: an example of the etho-ethnology of chimpanzees. Social Science Information 45: 227-63. http://dx.doi.org/10.1177/0539018406063642

Lalueza-Fox, C., A. Rosas, A. Estalrrich, E. Gigli, P.F. Campos, A. García-Tabernero,

S. García-VARGas, F. SÁNCHEZ-Quinto, O. Ramírez, S. Civit, M. Bastir, R. Huguet, D. Santamarfa, M.T.P. Gilbert, E. WillersleV \& M. DE LA Rasilla. 2011. Genetic evidence for patrilocal mating behavior among Neanderthal groups. Proceedings of the National Academy of Sciences of the USA 108: 250-53. http://dx.doi.org/10.1073/pnas.1011553108

Le Divellec, J. \& Y. Pécau. 2000. La grande cuisine aux herbes, algues, fruits et fleurs. Paris: Solar.

LordKipanidze, D., A. VEKUA, R. FERring, G.P. Rightmire, J. Agusti, G. Kiladze, A. Mouskhelishvili, M. Nioradze, M. Ponce DE LEÓN, M. TAPPEN \& C.P.E. ZOLliKOFER. 2005. Anthropology: the earliest toothless hominin skull. Nature 434: 717-18. http://dx.doi.org/10.1038/434717b

Lupo, K.D. \& D.N. SCHMITT. 1997. Experiments in bone boiling: nutritional returns and archaeological reflections. Anthropozoologica 25-26: 137-44.

MCKay, D.L. \& J.B. BlumberG. 2006. A review of the bioactivity and potential health benefits of chamomile tea (Matricaria recutita L.). Phytotherapy Research 20: 519-30. http://dx.doi.org/10.1002/ptr.1900 
Moncel, M.-H., A-M. Moigne \& J. Combier. 2012. Towards the Middle Paleolithic in Western Europe: the case of Orgnac 3 (south-eastern France). Journal of Human Evolution 63: 653-66. http://dx.doi.org/10.1016/j.jhevol.2012.08.001

OUTRAM, A.K. 2001. A new approach to identifying bone marrow grease exploitation: why the indeterminate fragments should not be ignored. Journal of Archaeological Science 28: 401-10. http://dx.doi.org/10.1006/jasc.2000.0619

Roebroecks, W. \& P. Villa. 2011. On the earliest evidence for habitual use of fire in Europe. Proceedings of the National Academy of Sciences of the USA 108: 5209-14. http://dx.doi.org/10.1073/pnas.1018116108

Roebroecks, W., M.J. Sier, T.K. Nielsen, D. DE LOECKER, J.M. PARÈs, C.E.S. ARPS \& H.J. MƯCHER. 2012. Use of red ochre by early Neandertals. Proceedings of the National Academy of Sciences of the USA 109: 1889-94. http://dx.doi.org/10.1073/pnas.1112261109

DE Roode, J.C., T. Lefèvre \& M.D. Hunter. 2013. Self-medication in animals. Science 340: 150-51. http://dx.doi.org/10.1126/science.1235824

SHERMAN, P.W. \& J. BILling. 1999. Darwinian gastronomy: why we use spices. BioScience 49: 453-63. http://dx.doi.org/10.2307/1313553
SPETH, J.D. 2004. Bouilli ou rôti : reconnaître les méthodes de cuisson et en démontrer l'importance. Les nouvelles de l'archéologie 95: 23-25.

- 2010. The paleoanthropology and archaeology of big-game hunting: protein, fat, or politics? New York: Springer.

Speth, J.D. \& K.A. SPIELmann. 1983. Energy source, protein metabolism, and hunter-gatherer subsistence strategies. Journal of Anthropological Archaeology 2: 1-31. http://dx.doi.org/10.1016/0278-4165(83)90006-5

Stefansson, V. 1944. Arctic manual. New York: Macmillan.

Wobber, V., B. Hare \& R. Wrangham. 2008. Great apes prefer cooked food. Journal of Human Evolution 55: 340-48. http://dx.doi.org/10.1016/j.jhevol.2008.03.003

Wrangham, R. 2009. Catching fire: how cooking made us human. New York: Basic.

ZIELINSKI, S. 2013. Stone Age stew? Soup making may be older than we'd thought. NPR News, 6 February 2013. Available at: http://www.npr.org/blogs/thesalt/2013/02/06/ $171104410 /$ stone-age-stew-soup-making-may-beolder-than-wed-thought (accessed 3 October 2014).

Received: 13 February 2014; Accepted: 4 June 2014; Revised: 6 June 2014 